\title{
Effect of Homoserine on Growth of Mycobacterium smegmatis: Inhibition of Glutamate Transport by Homoserine
}

\author{
By VENKATARAMAN SRITHARAN, COLIN RATLEDGE*AND \\ PAUL R. WHEELER \\ Department of Biochemistry, University of Hull, Hull HU6 $7 R X, U K$
}

(Received 21 April 1987)

\begin{abstract}
Homoserine strongly inhibited growth of Mycobacterium smegmatis in medium containing glutamate as the sole source of nitrogen but was without effect when asparagine, alanine or glutamine was the sole nitrogen source. It was readily taken up by glutamate-grown cells, reaching an intracellular concentration of over $20 \mathrm{~mm}$ after $4 \mathrm{~h}$ incubation. The primary site of action of homoserine was deduced to be the non-competitive inhibition of glutamate transport.
\end{abstract}

\section{INTRODUCTION}

In bacteria, homoserine is a branch-point amino acid intermediate in the biosynthesis of several amino acids of the aspartate pathway. It is converted both to threonine, and thus to isoleucine, and to methionine. In addition, the precursor of homoserine, aspartate $\beta$ semialdehyde, gives rise to diaminopimelic acid and lysine (Fig. 1) (Umbarger \& Davis, 1962). Thus the aspartate pathway is responsible for the synthesis of several protein amino acids as well as diaminopimelic acid used for cell wall biosynthesis. Mycobacteria generally grow well on a glycerol/salts medium containing asparagine or glutamate as the sole nitrogen source (Ratledge \& Hall, 1971; Lyon et al., 1967, 1974). When glutamate is used as the sole nitrogen source, it is likely that intracellular aspartic acid is derived from glutamate by transamination with oxaloacetate. Glutamate metabolism in mycobacteria has been studied in some detail (see Ratledge, 1982). Glutamate is taken up by an active transport mechanism (Yabu 1967, 1970) and is metabolized via both $\mathrm{NAD}^{+}$- and NADP+-dependent glutamate dehydrogenases whose properties in Mycobacterium smegmatis have been studied in some detail (Singh \& Venkitasubramanian, 1977).

Ostensibly, homoserine, being both a metabolite of aspartate and a precursor of several amino acids (see Fig. 1), would be expected to have little or no inhibitory action on growth but the reverse has proved to be the case. This has previously been noted with other bacteria (Kotre et al., 1973), including Escherichia coli, but the inhibition was sometimes incomplete and moreover in the case of $E$. coli (the other bacteria not being studied in this respect) was relieved by adding glutamate. In this work, we have studied the inhibition by homoserine of the growth of $M$. smegmatis utilizing glutamate as nitrogen source.

\section{METHODS}

Organisms and growth. Mycobacterium smegmatis NCIB 8548 was grown in $100 \mathrm{ml}$ glycerol/salts (Ratledge \& Hall, 1971) liquid medium containing either asparagine or glutamate $\left(5 \mathrm{~g} \mathrm{l}^{-1}\right)$ in $250 \mathrm{ml}$ conical flasks at $37^{\circ} \mathrm{C}$ with orbital shaking (200 r.p.m.). Except for DL-homoserine, all other amino acids were L-isomers. Additional amino acids including homoserine were added to the growth medium either before autoclaving or before inoculation.

Abbreitiations: NAD+-GDH, NAD ${ }^{+}$-dependent glutamate dehydrogenase; NADP+-GDH, NADP+. dependent glutamate dehydrogenase. 


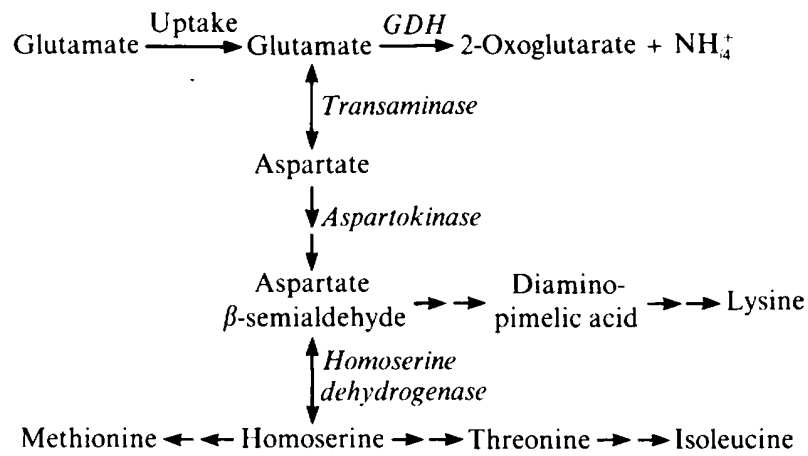

Fig. 1. Biochemical relationships of glutamate and aspartate to the amino acids derived from aspartate and homoserine.

Growth was monitored by determining the dry weight of $1 \mathrm{ml}$ samples (in duplicate) of growing cultures by drying the cells at $120^{\circ} \mathrm{C}$ for $3 \mathrm{~h}$. Cultures were harvested by filtration through Whatman no. 1 filter paper; the cells were washed with several volumes of distilled water and stored frozen at $-20^{\circ} \mathrm{C}$ until required.

Uptake of radioactive glutamic acid. Washed, intact cells of $M$. smegmatis were placed in tightly closed Eppendorf tubes containing, in I ml final volume, glycerol/magnesium/phosphate buffer $\left(0 \cdot 5 \mathrm{M}\right.$-glycerol $; 2 \mathrm{mM}^{-\mathrm{MgSO}_{4}} ; 0 \cdot 1 \mathrm{M}$ $\mathrm{KH}_{2} \mathrm{PO}_{4} / \mathrm{Na}_{2} \mathrm{HPO}_{4}$ buffer, pH 6.8) and $\left[\mathrm{U}^{-14} \mathrm{C}\right]$ glutamic acid $\left(20 \mu \mathrm{M}\right.$; sp. act. $\left.50 \mu \mathrm{Ci} \mathrm{mol}^{-1}, 1.85 \mathrm{MBq} \mathrm{mol}^{-1}\right)$. After incubation at $37^{\circ} \mathrm{C}$ for $15 \mathrm{~min}$ with continuous shaking (200 r.p.m.), the reaction was stopped by rapidly cooling the contents in ice (Lyon et al., 1967; Prasad et al., 1976). The cells were washed in the cold with the same buffer containing unlabelled glutamate and the radioactivity was determined by liquid scintillation counting in a scintillant containing butyl-PBD [2-(4'-t-butylphenyl)-5-(4"-biphenylyl)-1,3,4-oxadiazole] and Triton N-101 in xylene.

Preparation of cell-free extract. Bacteria were thawed and suspended in 10 times their volume of $50 \mathrm{~mm}$ $\mathrm{KH}_{2} \mathrm{PO}_{4} / \mathrm{Na}_{2} \mathrm{HPO}_{4}$ buffer, $\mathrm{pH} 8 \cdot 0$, containing $10 \mathrm{~mm}$-dithiothreitol and $10 \mathrm{~mm}$-EDTA and disrupted ultrasonically ( $80 \mathrm{~W}$ applied for 2 min followed by cooling) in a Branson Soniprobe Automatic Generator type $7533 \mathrm{~A}$ (USA) for $6 \mathrm{~min}$ ( $\mathrm{g}$ wet wt cells) -1 $^{-1}$ at 0 to $4^{\circ} \mathrm{C}$. The supernatant obtained after centrifuging the extract at $20000 \mathrm{~g}$ for $10 \mathrm{~min}$ was used for the assay of glutamate dehydrogenase, homoserine dehydrogenase and aspartokinase. Protein was estimated by a modified Lowry method (Layne, 1957).

Enzyme assays. NAD ${ }^{+}$-GDH (EC 1.4.1.2) and NADP+-GDH (EC 1.4.1.4) were assayed in the direction of oxidation of glutamate with the formation of NADH and NADPH being followed at $340 \mathrm{~nm}$ (Corman \& Inamdar, 1970). The assay mixture contained, in $1 \mathrm{ml}, 0.5 \mathrm{M}-\mathrm{Tris} / \mathrm{HCl}$ buffer $\mathrm{pH} 9 \cdot 0,0.4 \mathrm{~mm}-\mathrm{NAD}^{+}$or NADP $\mathrm{N}^{+}, 100 \mathrm{~mm}$ sodium glutamate and a suitable amount of cell extract protein as enzyme source. The contents were preincubated at $37^{\circ} \mathrm{C}$ and the reaction was started by adding glutamate. Enzyme activity was calculated from $\Delta A_{340}$ measured over $5 \mathrm{~min}$ and expressed as $\mu \mathrm{mol}$ NADH or NADPH formed $\mathrm{min}^{-1}(\mathrm{mg} \text { protein })^{-1}$. A control lacking glutamate was run each time.

Aspartokinase (EC 2.7 .2 .4$)$ was assayed by detecting the aspartate hydroxamate $\left(\varepsilon_{520}=3501 \mathrm{~mol}^{-1} \mathrm{~cm}^{-1}\right)$ formed during a $1 \mathrm{~h}$ incubation (Stadtman et al., 1961) except that the $\mathrm{FeCl}_{3}$ reagent was prepared as described by Truffa-Bachi et al. (1970) and the final colour was developed with $3 \mathrm{ml}$ of this reagent. Homoserine dehydrogenase (EC 1.1.1.3) was assayed using DL-homoserine as the substrate and $\mathrm{NADP}^{+}$as coenzyme (Datta \& Gest, 1965). Controls were performed for both enzymes by omitting aspartate and homoserine from the respective assay mixtures. Specific activity of homoserine dehydrogenase was expressed as units (mg protein) ${ }^{-1}$, where $1 \mathrm{U}$ enzyme converts substrate to measured product at $1 \mu \mathrm{mol} \mathrm{min}^{-1}$.

Determination of the intracellular homoserine concentration. DL-Homoserine was added at $5 \mathrm{mM}$ to a $100 \mathrm{ml}$ culture of $M$. smegmatis after $2 \mathrm{~d}$ growth on glutamate medium. After a further $4 \mathrm{~h}$ growth, the cells were filtered, washed three times with cold $0.9 \% \mathrm{NaCl}$ solution and then extracted, according to the procedure of Herbert et al. (1971), with boiling water for $30 \mathrm{~min}$ and subsequently with $60 \%(\mathrm{v} / \mathrm{v})$ ethanol at $4{ }^{\circ} \mathrm{C}$ for $60 \mathrm{~min}$. The two extracts containing the soluble amino acids were pooled, evaporated at $50{ }^{\circ} \mathrm{C}$ and redissolved in $0.5 \mathrm{ml} 0.5 \mathrm{M}-\mathrm{Tris} / \mathrm{HCl}$ buffer, $\mathrm{pH} 9.0$. The amount of $\mathrm{L}$-homoserine in the aqueous extract was estimated by adding a sample to a cell-free extract from $M$. smegmatis containing homoserine dehydrogenase and determining the reaction velocity upon the addition of $\mathrm{NADP}^{+}$and thus the substrate concentration. A control was also carried out using the soluble amino acid pool obtained from cells not exposed to homoserine. 


\section{RESULTS AND DISCUSSION}

\section{Physiological effects of homoserine on M. smegmatis}

$M$. smegmatis grows well in glycerol/salts medium containing either asparagine or glutamate as sole nitrogen source. When DL-homoserine, at $5 \mathrm{~mm}$, was added to medium containing glutamate, growth was severely restricted and did not recover even after $7 \mathrm{~d}$ (Fig. 2). As the same magnitude of effect was produced using $2.5 \mathrm{mM}$-L-homoserine, it was concluded that the Disomer was without effect. All subsequent experiments used DL-homoserine. With DLhomoserine at $1 \mathrm{mM}$, the yield of bacteria after $4 \mathrm{~d}$ growth was still decreased by $60 \%$ (results not shown). If homoserine ( $5 \mathrm{~mm}$, final concn) was added to the glutamate medium after $48 \mathrm{~h}$, growth was again inhibited (Fig. 2).

The intracellular concentration of L-homoserine was determined in a 48 h culture of $M$. smegmatis, which had been exposed to $5 \mathrm{mM}$ DL-homoserine for $4 \mathrm{~h}$ (see Methods), as being $5 \cdot 65$ $\mu \mathrm{mol}$ per $100 \mathrm{mg}$ dry cells. Without exposure to homoserine, a value of $1.0 \mu \mathrm{mol}$ per $100 \mathrm{mg}$ dry cells was obtained which was attributed to the general reactivity of the soluble amino acid pool towards the crude enzyme assay system being used. Thus the difference between the two values was attributed to the presence of L-homoserine and, if a cell volume of approximately $2 \mu \mathrm{l}(\mathrm{mg}$ dry wt) $)^{-1}$ is assumed as a typical value for bacteria (Midgley \& Dawes, 1973), this is equivalent to $23 \mathrm{mM}$.

The absence of any inhibition with medium containing asparagine or alanine as nitrogen sources (results not shown) suggested that homoserine was acting against the utilization of glutamate itself rather than on a central pathway of metabolism. However, it was felt important to substantiate such a deduction experimentally. If homoserine was inhibiting a central pathway, the most logical point would be an enzyme of the aspartate pathway of amino acid biosynthesis (see Fig. 1), i.e. aspartokinase or homoserine dehydrogenase, or both.

Aspartokinase was detected in cell extracts prepared from $M$. smegmatis incubated in glycerol/glutamate medium containing DL-homoserine ( $5 \mathrm{~mm}$ ) for $9 \mathrm{~d}$. (Cells were pooled from several flasks to provide enough material. Approximately $500 \mathrm{mg}$ wet weight of cells could be obtained from 10 flasks.) In these extracts $0.40 \mu \mathrm{mol}$ aspartate hydroxamate was formed $\mathrm{h}^{-1}$ (mg protein $)^{-1}$. DL-Homoserine when added to the enzyme assay at $5 \mathrm{~mm}$ caused nearly $45 \%$ inhibition of activity; at $20 \mathrm{~mm}$ it gave $70 \%$ inhibition. The specific activity of the aspartokinase $\left.\left[0.44 \mu \mathrm{mol} \text { aspartate hydroxamate formed } \mathrm{h}^{-1} \text { (mg protein }\right)^{-1}\right]$ was, however, almost unchanged in comparison with those recovered from cells grown on glutamate in the absence of homoserine, indicating that no repression of enzyme synthesis had occurred. Homoserine dehydrogenase, which was present in the same cell extracts at $5.9 \mathrm{mU}(\mathrm{mg} \text { protein })^{-1}$, was unaffected by DLhomoserine at either 5 or $20 \mathrm{~mm}$ but its synthesis was repressed by $70 \%$ when DL-homoserine (at $5 \mathrm{mM}$ ) had been included in the growth medium.

Thus, as homoserine partially inhibits aspartokinase and partially represses homoserine dehydrogenase, its effects, if it were only acting on these two enzymes, should be reversed by adding into the growth medium those amino acids whose biosynthesis depend upon the two enzymes: lysine, diaminopimelic acid, methionine, threonine and isoleucine. However, no single amino acid or combination of amino acids completely reversed the effect of homoserine (data not shown). Although growth up to $80 \%$ of control rates (results not shown) was found when threonine, isoleucine and methionine were added together this was attributed to the added amino acids (each at $5 \mathrm{~mm}$ ) reversing the effects of homoserine by acting as alternative nitrogen sources to glutamate, since the effect of homoserine was confined to cells utilizing glutamate.

We therefore conclude that homoserine, in spite of its partial inhibitory effect towards aspartokinase and repression of homoserine dehydrogenase, probably interferes with the utilization of glutamate, as the effect is manifested only in the presence of this nitrogen source.

\section{Utilization of glutamate by $M$. smegmatis}

Utilization of glutamate involves transport into the cells followed by either oxidation (via glutamate dehydrogenase/s) or transamination (see Fig. 1). 


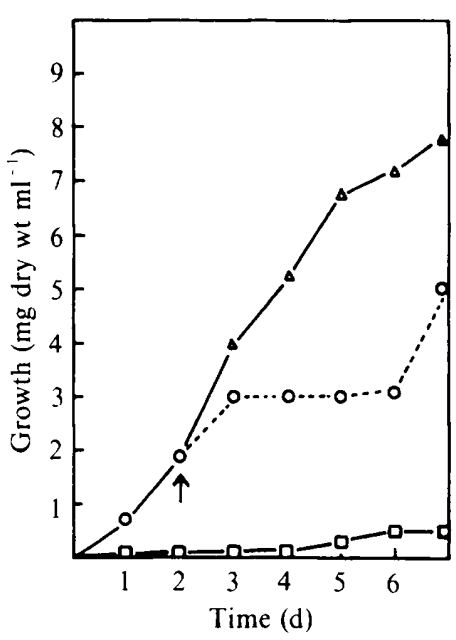

Fig. 2

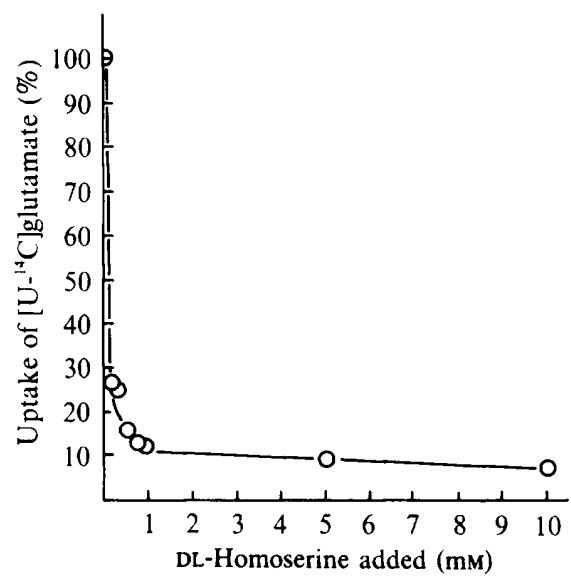

Fig. 3

Fig. 2. Effect of homoserine on growth of $M$. smegmatis on glycerol/glutamate medium. Growth was followed by determining in duplicate the dry weight of cells drawn from culture media periodically in the absence $(\triangle)$ and presence $(\square)$ of $5 \mathrm{~mm}$-DL-homoserine; DL-homoserine added at $5 \mathrm{~mm}$ (indicated by arrow) after $2 \mathrm{~d}$ growth $(\mathrm{O})$. The experiment was carried out three times and the results given are for a typical experiment.

Fig. 3. Uptake of L-glutamic acid by washed cells of $M$. smegmatis previously grown on glutamate ( 20 $\mathrm{mM}$ ) medium. Experimental details are given in Methods. The $100 \%$ value corresponds to $0.33 \mu \mathrm{mol}$ glutamic acid (20500 c.p.m.). The experiment was carried out four times in duplicate and the results given are for a typical experiment.

Effect of homoserine on glutamate uptake. $M$. smegmatis possesses an active transport system for glutamate which is saturable, and has in addition a passive but non-saturable diffusion process (Yabu, 1970, 1971). The transport of glutamate into $M$. smegmatis was severely impaired by homoserine (Fig. 3). By plotting the results, as well as those for glutamate uptake in the absence of homoserine, in the usual double reciprocal manner, the inhibition kinetics of glutamic transport in the presence of homoserine was found to be non-competitive ( $K_{\mathrm{i}}=150 \mu \mathrm{M}$ for the DL-isomer, i.e. $75 \mu \mathrm{M}$ for the L-isomer). Increasing the glutamate concentration did not improve the uptake of glutamate significantly. The low rate of glutamate uptake remaining in the presence of homoserine was considered to be due to diffusion.

The inhibition of glutamate uptake by homoserine was specific and was unaffected by $5 \mathrm{~mm}$ threonine, methionine or isoleucine (data not shown). Uptake of glutamate into washed cells of $M$. smegmatis, previously grown on asparagine or glutamine medium, was also similarly inhibited by homoserine (results not presented).

Effect of homoserine on endogenous metabolism of glutamate. $M$. smegmatis possessed activities of both NADP ${ }^{+}$and $\mathrm{NAD}^{+-} \mathrm{GDH}$ at $90 \mathrm{mU}(\mathrm{mg} \text { protein })^{-1}$ and $5.7 \mathrm{mU}(\mathrm{mg} \text { protein })^{-1}$, respectively, in extracts from glutamate-grown cells. The two enzymes had different $\mathrm{pH}$ optima ( 8.0 for $\mathrm{NADP}^{+}-\mathrm{GDH}$ and 9.0 for $\mathrm{NAD}^{+}-\mathrm{GDH}$ ) and different electrophoretic mobilities (not shown). Thus we conclude that the two GDH activities are carried by two separate proteins in M. smegmatis. DL-Homoserine at $5 \mathrm{~mm}$ inhibited NAD ${ }^{+}-\mathrm{GDH}$ by $40 \%$ and at $50 \mathrm{~mm}$ by $65 \%$ but had less effect on NADP ${ }^{+}$-GDH even at the highest concentrations (up to $50 \mathrm{~mm}$ ) (data not shown). The specific inhibition of $\mathrm{NAD}^{+}-\mathrm{GDH}$ by homoserine could also be demonstrated after separating the GDHs by PAGE and carrying out activity staining in the presence and absence of homoserine.

Although Kotre et al. (1973) and Savageau et al. (1972) previously noted that the growth of a range of micro-organisms was inhibited by high concentrations of homoserine (15 $\mathrm{mM})$, this could be reversed, at least with $E$. coli $\mathrm{B} / \mathrm{r}$, by adding glutamate to the growth medium. They 
concluded that the inhibition resulted from the sensitivity of $\mathrm{NADP}^{+}-\mathrm{GDH}$ to homoserine. Presentation to the cells of glutamate - the product of the inhibited reaction - then relieved the inhibition. This is clearly distinct from the phenomenon we have observed here with $M$. smegmatis, where homoserine exerts its effect only when glutamate is sole nitrogen source. The evidence which we have presented would indicate that the primary cause of inhibition is the almost total prevention of glutamate uptake into the cells. Inhibition of other enzyme activities (NAD ${ }^{+}-\mathrm{GDH}$ and aspartokinase) and repression of enzyme synthesis (homoserine dehydrogenase) then become secondary to this main effect. The consequences of glutamate deprivation as the sole nitrogen source to the cells are then self-evident.

V.S. is supported by the Commonwealth Scholarship Commission (UK) and P.R.W. thanks the MRC for support.

\section{REFERENCES}

CORMAN, L. \& INAMDAR, A. (1970). L-Glutamate dehydrogenase. Methods in Enzymology 17, 844-849.

DATTA, P. \& GEST, H. (1965). Homoserine dehydrogenase of Rhodospirillum rubrum. Purification, properties and feedback control of activity. Journal of Biological Chemistry 240, 3023-3033.

Herbert, D., Phipps, P. J. \& Strange, R. E. (1971). Chemical analysis of microbial cells. Methods in Microbiology 5B, 210-336.

Kotre, A. M., Sullivan, S. J. \& Savageal, M. A. (1973). Metabolic regulation by homoserine in Escherichia coli B/r. Journal of Bacteriology 116, 663672

LAYNE, B. (1957). Spectrophotometric and turbidimetric methods for measuring proteins. Methods in Enzymology 3, 447-454.

Lyon, R. H., Rogers, P., Hall, W. H. \& Lichstein, H. C. (1967). Inducible glutamate transport in mycobacteria and its relation to glutamate oxidation. Journal of Bacteriology 94, 92-100.

Lyon, R. H., Hall, W. H. \& Martinez, C. C. (1974). Fffect of L-asparagine on growth of Mycobacterium tuberculosis and utilization of other amino acids. Journal of Bacteriology 17, 151-156.

MIDGLEY, M. \& DAwES, E. A. (1973). The regulation of glucose transport and methyl $\alpha$-glucoside in Pseudomonas aeruginosa. Biochemical Journal 132, 141-154.

Prasad, R., Kalra, V. K. \& Brodie, A. F (1976). Different mechanisms of energy coupling for transport of various amino acids in cells of Mycobacterium phlei. Journal of Biological Chemistry 251, 2493-2498.

RATlEDGE, C. (1982). Nutrition, growth and metabolism. In Biology of Mycobacteria, vol. 1, pp. 186271. Edited by C. Ratledge \& J. L. Stanford. London: Academic Press.
Ratledge, C. \& Hall, M. J. (1971). Influence of metal ions on the formation of mycobactin and salicylic acid in Mycobacterium smegmatis grown in static culture. Journal of Bacteriology 108, 312-319.

Savagead, M. A., Kotre, A. M. \& Sakamoto, N. (1972). A possible role in the regulation of primary amination for a complex of glutamine : $\alpha$-ketoglutarate amido transferase and glutamate dehydrogenase in Escherichia coli. Biochemical and Biophysical Research Communications 48, 41-47.

Singh, P. \& Venkitasubramanian, T. A. (1977). Glutamate dehydrogenase of Mycobacterium smegmatis. Indian Journal of Biochemistry and Biophysics 14, 379-381.

Stadtman, E. R., Cohen, G. N., Le Bras, G. \& De RoBichoN-SzUlmaJsTeR, H. (1961). Feedback inhibition and repression of aspartokinase activity in Escherichia coli and Saccharomyces cerevisiae. Journal of Biological Chemistry 236, 2033-2038.

Truffa-Bachi, P. \& Cohen, G. N. (1970). Aspartokinase I and homoserine dehydrogenase I (E.coli). Methods in Enzymology 17A, 694-698.

Umbarger, E. \& Davis, B. D. (1962). Pathways of amino acid metabolism. In The Bacteria, vol. 3, pp. 167-252. Edited by I. C. Gunsalus \& R. Y. Stanier. New York: Academic Press.

YABU, K. (1967). The uptake of D-glutamic acid by Mycobacterium avium. Biochimica et biophysica acta 135, 181-183.

YABU, K. (1970). Amino acid transport in Mycobacterium smegmatis. Journal of Bacteriology 102, 6-13.

YABU, K. (1971). Aspartic acid transport in Mycobacterium smegmatis. Japanese Journal of Microbiology $15,449-456$. 